\title{
Analysis of Production and Consumption of Electric Energy in the Green Office of UTFPR in Curitiba
}

\author{
Larissa Barbosa Krasnhak ${ }^{1 *}$, Elis Almeida Medeiros de Mello ${ }^{1}$, Guilherme R. Moura ${ }^{1}$, \\ Francielle da Rocha Santos ${ }^{1}$, Jair Urbanetz Junior ${ }^{1,2}$ \\ ${ }^{1}$ Programa de Pós-Graduação em Engenharia Civil, Universidade Tecnológica Federal do Paraná, Curitiba, Brasil; \\ 2 Programa de Pós-Graduação em Sistemas de Energia, Universidade Tecnológica Federal do Paraná, Curitiba, \\ Brasil.
}

\begin{abstract}
The increasing demand for electricity and the scarcity of resources, require renewable energy sources and efficient equipment that reduce the consumption of electricity. The Green Office (GO) of the Universidade Tecnologica Federal do Paraná (UTFPR) is a sustainable building that uses strategies to reduce impacts to the environment, one of them being the use of the grid connected photovoltaic system (on-grid). The on-grid was installed in 2011 and since then has been feeding the GO and another building (block V) belonging to UTFPR. This article presents a comparison between an estimate of energy consumption and the generation of energy through the on-grid. By means of the estimated consumption, a survey in loco of the scenario of expenditures of the electrical equipment used in the GO was made, estimating hours of use and power, so the consumption scenario was $145 \mathrm{kWh} / \mathrm{month}$. The power generation of the EV is lower in the months May - July, period in which the solar irradiation is smaller, but according to the measurements the on-grid produces more energy than it consumes.
\end{abstract}

Key words: Green Office, Photovoltaic Solar Energy, Energy consumption, Energy production.

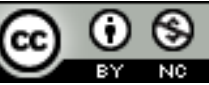

*Author for correspondence: larissabarbosakrasnhak@gmail.com 


\section{INTRODUCTION}

In an implementation plan developed at the World Summit on Sustainable Development in Johannesburg in 2012, the United Nations has defined some objectives to mitigate socio-environmental impacts, one of which is to encourage the production of energy that is economically viable, socially acceptable and from sustainable renewable and clean sources. Within this line, one can find solar, wind, biomass, geothermal, hydraulic, among other sources that contribute to the diversification of the world energy matrix, enabling the mentioned actions [1].

In Brazil, the energy matrix is predominantly renewable and the hydroelectric source accounts for $64 \%$ of all energy generated in the country according to [2], carried out by the Energy Research Company.

Photovoltaic solar energy showed a very significant growth among the sources of energy considered renewable, both in the world and in the Brazilian scenarios. In the Brazilian scenario, according to [3], 13.233 photovoltaic units of the mini and micro power generation system are installed in the compensation system, totalizing 106,2 MW of installed capacity in the grid-connected Photovoltaic System (SFVCR ${ }^{1}$ ) in Brazil, only in the Energy Compensation System.

However, among all sources of energy mentioned, photovoltaic solar energy is the most abundant, inexhaustible and clean compared to other sources of renewable energy, considering that the hydroelectric plants have more critical situations in the periods of drought, leading to an increase of demand [4].

In this context, the Universidade Tecnológica Federal do Paraná (UTFPR) has designed the Green Office (GO), a sustainable building that uses innovative technologies. The Green Office is located in Curitiba and has $150 \mathrm{~m}^{2}$ distributed on 2 floors. In its construction, several sustainability strategies were adopted, such as: photovoltaic solar energy production, use of rainwater, green roof, recycled materials, certified and with low impact to the environment, among others.

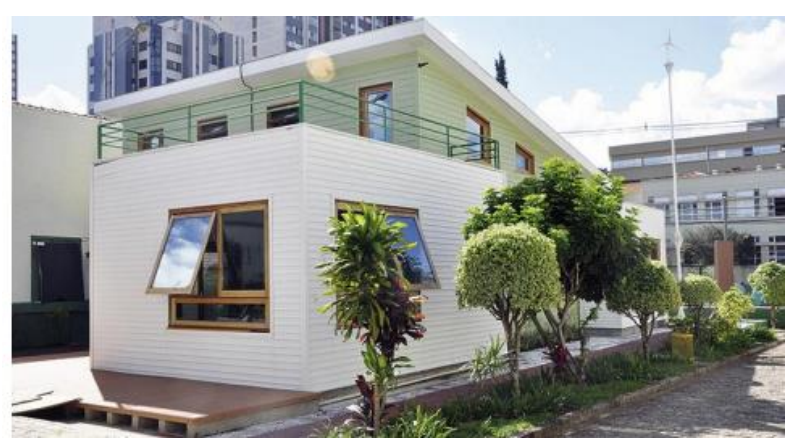

Figure 1 - Green Office

Source: [5]

In the GO, two models of photovoltaic system are installed, one being connected to the grid and an isolated one. Design strategies are used to reduce the energy consumption of the building as natural lighting and LED lamps. The Photovoltaic System Connected to the Electrical Network is based on the interaction of the utility and the photovoltaic generator, with solar incidence on the photovoltaic panel the energy is generated and made available for use. As for the isolated system, it consists of a bank of batteries that are fed during the period that the panel is generating energy and in the period of no generation, the batteries feed specific loads. In this paper we compared power generation data with a power consumption scenario in the GO, with a qualitative

\footnotetext{
${ }^{1}$ In Portuguese "Sistema Fotovoltaico Conectado à Rede".
} 
approach by means of an in loco analysis of the equipment used in the GO, measurement of actual consumption and generation data of the SFVCR collected.

\section{FEATURES OF THE UTFPR GREEN OFFICE SFVCR}

The Photovoltaic Solar System connected to the Electrical Network is installed on the roof of the Green Office and consists of 10 photovoltaic modules connected in series of KYOCERA brand, model KD210GX-LP (polycrystalline silicon technology) shown in Figure 2, connectors and a single-phase inverter in $220 \mathrm{~V}$ of $2 \mathrm{~kW}$ nominal power of the brand PVPOWERED model PVP2000 shown in Figure 3, having an installed power of $2,1 \mathrm{kWp}$.

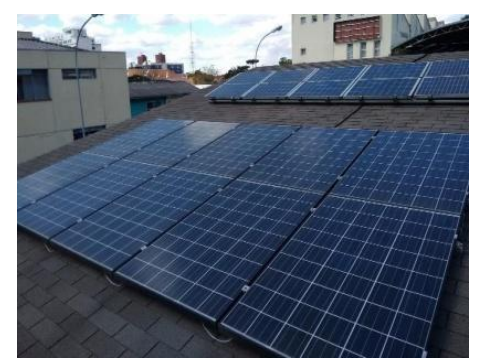

Figure 2 - PV panel of the UTFPR GO central campus. Source: Authors

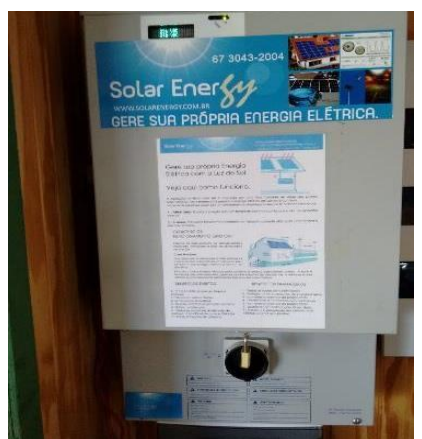

Figure 3 - Inverter of the UTFPR GO central campus. Source: Authors

The area covered by the roof of the building where the photovoltaic panel is installed has an area of $15 \mathrm{~m}^{2}$. Figure 2 shows the panel installed on the roof of the building and Figure 3, the inverter of the Photovoltaic System Connected to the Electrical Network in the UTFPR Green Office.

\section{ELECTRICAL ENERGY CONSUMPTION SCENARIO}

The Green Office has an exclusive consumption meter for the building, but it was not monitored, so it was necessary to create a consumption scenario to estimate the electricity consumed in the GO. For that purpose, it was necessary a visual and photographic survey in loco of all the equipment used in the building, as: artificial lighting system, refrigeration equipment, computers and media equipment, among others, [4]. Firstly, the nomenclature of lighting equipment and its distribution according to Figure 4, Figure 5 and Figure 6 were followed. 


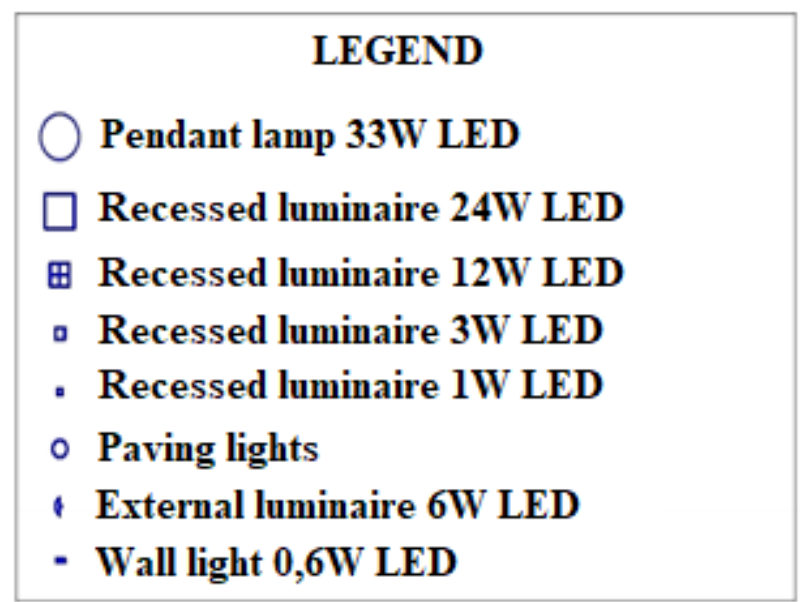

Figure 4 - lamps.

Source: [6]

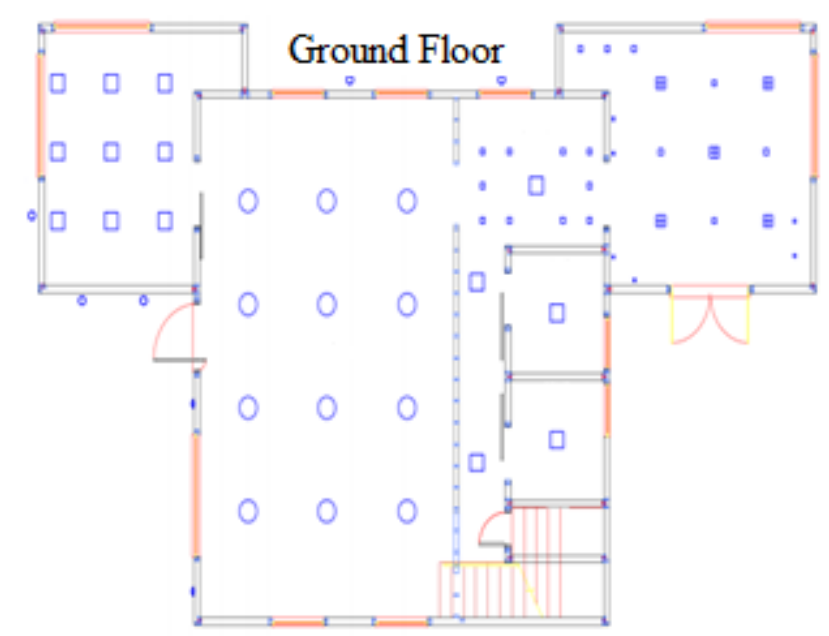

Figure 5 - GO schematic plan - ground floor.

Source: [6].

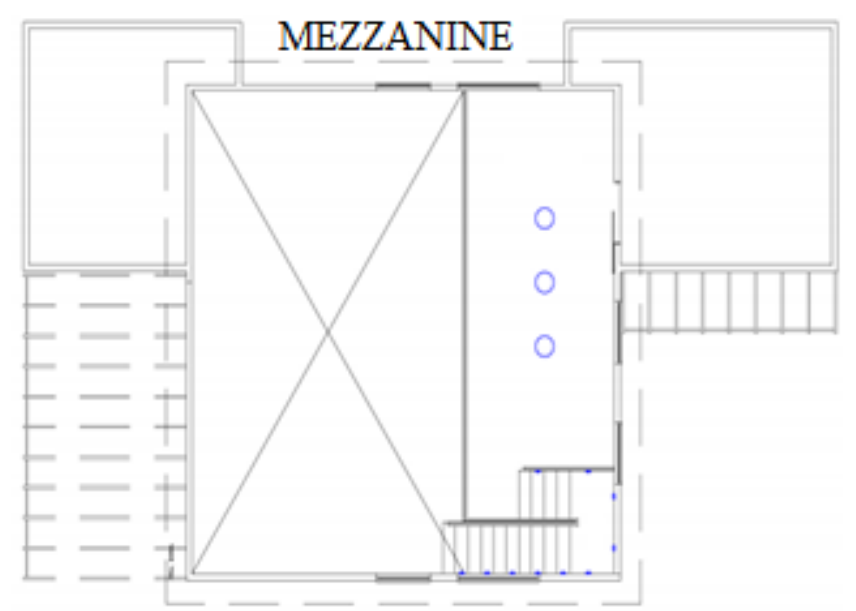

Figure 6 - GO schematic plan - mezzanine.

Source: [6]. 
The technical information of the equipment used in the artificial lighting of the EV was identified and raised, which served to create this scenario of consumption. The other power data were obtained in the equipment datasheets or average powers of equipment found in the market. The equipment considered was the one with considerable energy consumption and the internal part of the illumination.

The consumption scenario was based on three measurements performed in the GO. In the measurement of consumption of the month of May/2017, the energy meter reading from the beginning to the end of that month was recorded and the difference obtained between the two data indicated the consumption of the month. The same procedure was performed for the month of June/2017 and July/2017. The result obtained in the month of May/2017 was $155,73 \mathrm{kWh}$, parameter used as basis for the creation of the consumption scenario, Figure 7.

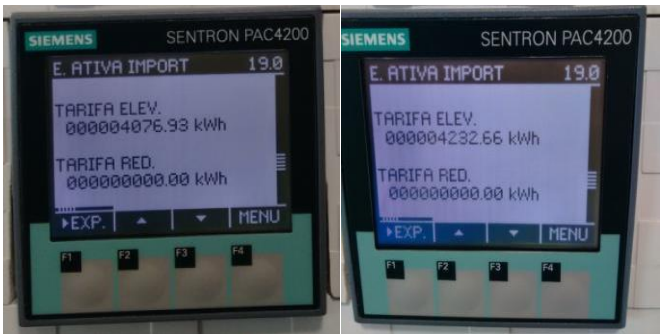

Figure 7 - GO consumption in the month of May.

Source: Authors

In the following 30 days the consumption was $103,83 \mathrm{kWh}$, representing the month of June/2017, according to Figure 8.

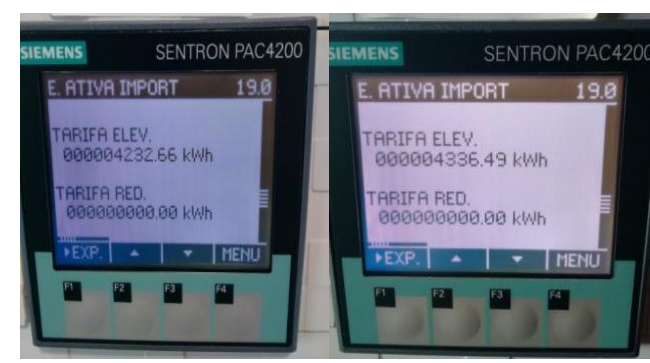

Figure 8 - GO consumption in the month of June.

Source: Authors

Figure 9, below, shows that consumption for the month of July/2017: 117,16 kWh.

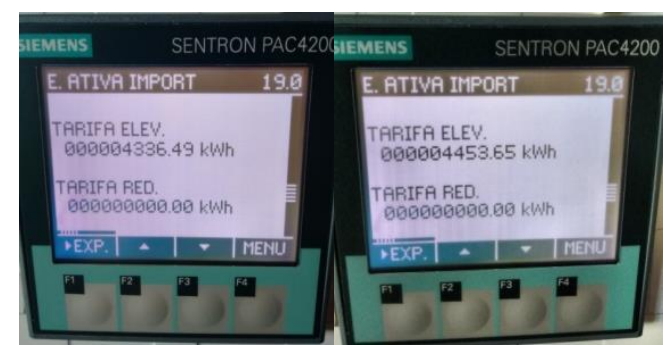

Figure 9 - GO consumption in the month of July. Source: Authors

Then, with the survey performed and the consumption measured in the months of May, June and July 2017, it was possible to create a scenario of equipment usage, making a conservative estimate with the closest value of the May/2017 measurement. It was assumed that the GO was open from Monday to Friday and the time of use of the 
equipment was estimated according to conversation with the users and are indicated in Table 1 .

Table 1 - GO consumption scenario.

\begin{tabular}{|c|c|c|c|c|}
\hline LOCAL & EQUIPMENT & QUANTITY & POWER (W) & $\begin{array}{l}\text { HOURS USED } \\
\text { PER WEEK }\end{array}$ \\
\hline Coffee room & Recessed luminaire $12 \mathrm{~W}$ & 5 & 12 & 15 \\
\hline Coffee room & Recessed luminaire $3 \mathrm{~W}$ & 7 & 3 & 15 \\
\hline Coffee room & Recessed luminaire $1 \mathrm{~W}$ & 4 & 1 & 15 \\
\hline Coffee room & Coffee machine & 1 & 1000 & 5 \\
\hline Catalog room & Recessed luminaire $3 \mathrm{~W}$ & 10 & 3 & 10 \\
\hline Catalog room & Recessed luminaire $24 \mathrm{~W}$ & 1 & 24 & 10 \\
\hline Circulation & Recessed luminaire $24 \mathrm{~W}$ & 2 & 24 & 5 \\
\hline Bathroom & Recessed luminaire $24 \mathrm{~W}$ & 1 & 24 & 3 \\
\hline Bathroom & Recessed luminaire $24 \mathrm{~W}$ & 1 & 24 & 3 \\
\hline Office & Pendent lamp 33W & 12 & 33 & 20 \\
\hline Office & Computer & 1 & 250 & 10 \\
\hline Office & Multimedia equipment & 1 & 308 & 10 \\
\hline Coordination & Recessed luminaire $24 \mathrm{~W}$ & 9 & 24 & 5 \\
\hline Coordination & Printer & 1 & 18,5 & 1 \\
\hline Coordination & Computer & 1 & 250 & 15 \\
\hline Coordination & Telephone & 1 & 1,6 & 2 \\
\hline Escada & Paving lights & 10 & 0,6 & 2 \\
\hline Mezzanine & Pendent lamp 33W & 3 & 33 & 5 \\
\hline Mezzanine & Computer & 2 & 250 & 20 \\
\hline Mezzanine & Portable air conditioning & 1 & 280 & 0 \\
\hline
\end{tabular}

Source: Authors

With the consumption scenario, it is estimated that the GO consumes 154,53 $\mathrm{kWh} /$ month in the 30-day months and no academic recess. Then, a scenario was created for the period from August 2016 to July 2017, as illustrated in Table 2, considering the number of days in the month and that during the holiday months (January, July and December) the GO only consumes $70 \%$ of school months.

Table 2 - GO consumption estimate.

\begin{tabular}{lcccccccccccc}
\multicolumn{1}{c}{\begin{tabular}{c} 
Month \\
\multicolumn{1}{c}{ Year }
\end{tabular}} & $\begin{array}{c}\text { aug } \\
\mathbf{2 0 1 6}\end{array}$ & $\begin{array}{c}\text { sep } \\
\mathbf{2 0 1 6}\end{array}$ & $\begin{array}{c}\text { oct } \\
\mathbf{2 0 1 6}\end{array}$ & $\mathbf{2 0 1 6}$ & $\mathbf{2 0 1 6}$ & $\mathbf{2 0 1 7}$ & $\mathbf{2 0 1 7}$ & $\mathbf{2 0 1 7}$ & $\mathbf{2 0 1 7}$ & $\mathbf{2 0 1 7}$ & $\mathbf{2 0 1 7}$ & $\mathbf{2 0 1 7}$ \\
\hline $\begin{array}{l}\text { Daily consumption } \\
\text { (kWh) }\end{array}$ & 5,15 & 5,15 & 5,15 & 5,15 & 3,61 & 3,61 & 5,15 & 5,15 & 5,15 & 5,15 & 5,15 & 3,61 \\
\hline $\begin{array}{l}\text { Number of days in the } \\
\text { month }\end{array}$ & 31 & 30 & 31 & 30 & 31 & 31 & 28 & 31 & 30 & 31 & 30 & 31 \\
\hline $\begin{array}{l}\text { Monthly consumption } \\
\text { (kWh) }\end{array}$ & 160 & 155 & 160 & 155 & 112 & 122 & 144 & 160 & 155 & 160 & 155 & 112 \\
\hline
\end{tabular}

Source: Authors 


\section{SFVCR GENERATION AND PERFORMANCE DATA}

The irradiation data are collected on the INMET website, related to the existing A-807 station in Curitiba, since the implementation of the SFVCR in the GO in December 2011 and compiled so that several analyzes can be performed. The INMET pyranometer is installed horizontally, so it is necessary to use a software to determine the actual irradiance in the inclined plane of the modules. Thus, the use of the radiasol software, freely available by the Universidade Federal do Rio Grande do Sul [7], was chosen.

Data are also collected from electric power generation of the SFVCR of the GO. Since 2012 this collection has been carried out to monitor the system and also for analyzes and studies.

With the data of generation, the energy generated in the last year, according to Graph 1, was compiled.

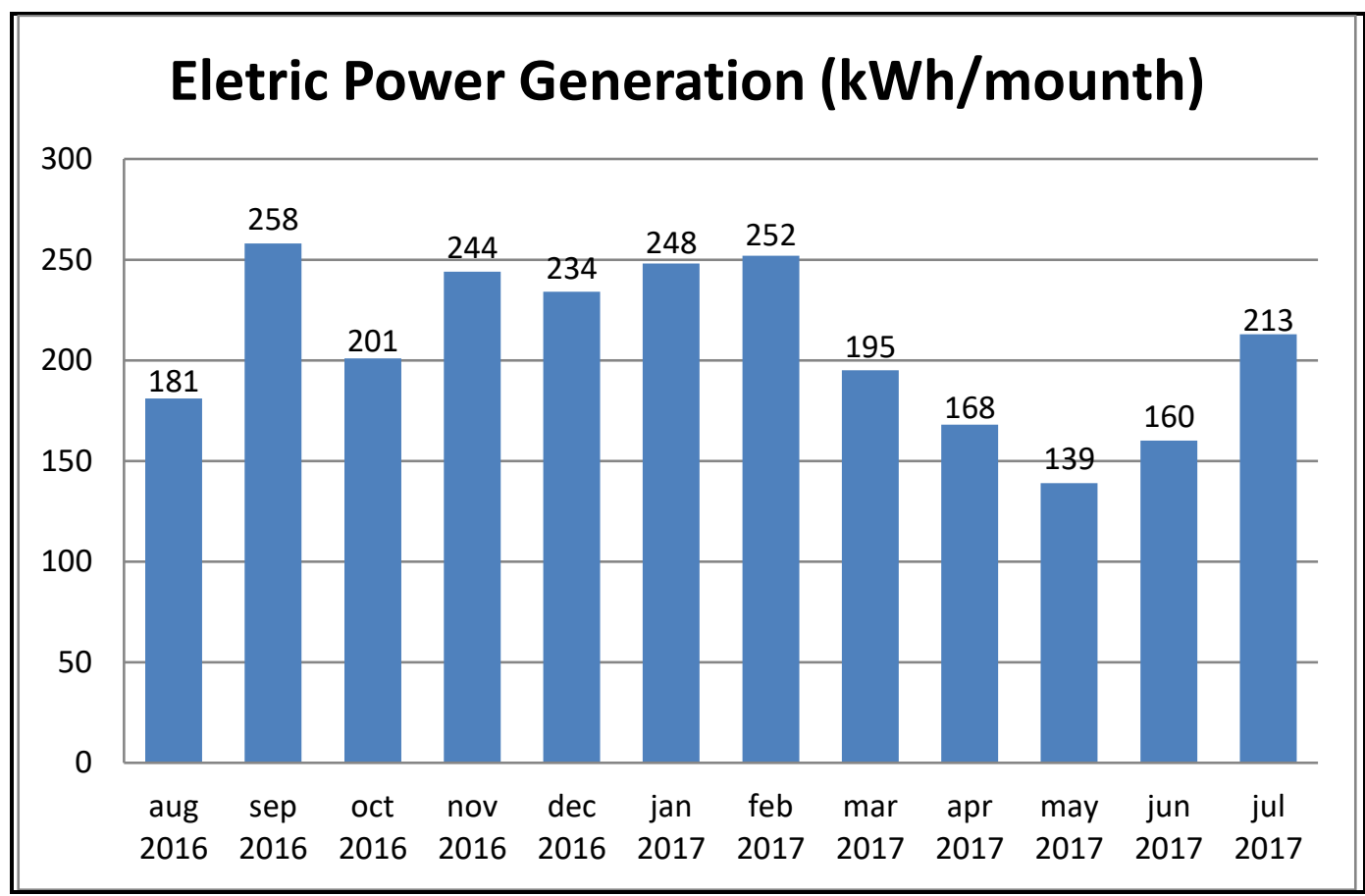

Graph 1 - Generation of 1 year of electric energy in GO.

Source: Authors

In the analyzed period, the month of May 2017 presented the smallest generation and September 2016 the greatest one. The GO SFVCR merit indices observed between 2012 and 2016 are: Productivity $=1.111 \mathrm{kWh} / \mathrm{kWp}$; Performance Ratio $=70 \%$ and Capacity Factor $=12,7 \%$. The SFVCR of the EV, as well as its individual components (modules and inverter), meet the current standards in the country, such as NBR16274/2014 and NBR 11876/2010.

\section{DISCUSSION}

For the comparison of the results obtained, Table 3 was elaborated with the data of the consumption estimate and data of power generation of the GO SFVCR between August/2016 and July/2017. The average generation of energy in the period was 208 $\mathrm{kWh} /$ month and consumption $145 \mathrm{kWh} /$ month. 
Table 3- GO comparison between consumption and energy generation.

\begin{tabular}{lcccccccccccc}
\multicolumn{1}{c}{$\begin{array}{c}\text { Month } \\
\text { Year }\end{array}$} & $\begin{array}{c}\text { aug } \\
\text { 2016 }\end{array}$ & $\begin{array}{c}\mathbf{2 0 1 6} \\
\mathbf{2 0 1 6}\end{array}$ & $\begin{array}{c}\text { oct } \\
\mathbf{2 0 1 6}\end{array}$ & $\begin{array}{c}\mathbf{2 0 1 6} \\
\mathbf{2 0 1 6}\end{array}$ & $\begin{array}{c}\text { dec } \\
\mathbf{2 0 1 7}\end{array}$ & $\begin{array}{c}\mathbf{2 0 1 7} \\
\mathbf{2 0 1 7}\end{array}$ & $\mathbf{2 0 1 7}$ & $\mathbf{2 0 1 7}$ & $\mathbf{2 0 1 7}$ & $\mathbf{2 0 1 7}$ \\
\hline $\begin{array}{l}\text { Power Generation } \\
\text { (kWh) }\end{array}$ & 181 & 258 & 201 & 244 & 234 & 248 & 252 & 195 & 168 & 139 & 160 & 213 \\
\hline $\begin{array}{l}\text { Estimated consumption } \\
\text { (kWh) }\end{array}$ & 160 & 155 & 160 & 155 & 112 & 112 & 144 & 160 & 155 & 160 & 155 & 112 \\
\hline Energy excess (kWh) & 21 & 103 & 41 & 89 & 122 & 136 & 108 & 35 & 13 & -21 & 5 & 101 \\
\hline $\begin{array}{l}\text { Accumulated result } \\
\text { (kWh) }\end{array}$ & 21 & 125 & 166 & 256 & 378 & 514 & 622 & 657 & 671 & 650 & 655 & 757 \\
\hline
\end{tabular}

Source: Authors

With the results obtained, it is concluded that the Green Office is a positive energy construction. The concept of zero energy building, which, according to the authors [8], are constructions where the energy generated is equal to the energy required to meet the demands of the building is reached and overcome in the GO, because the production of energy of the SFVCR is higher than the consumption of the office. In Graph 2, below, it is possible to visualize the difference between the consumption and the generation of electric power in the period.

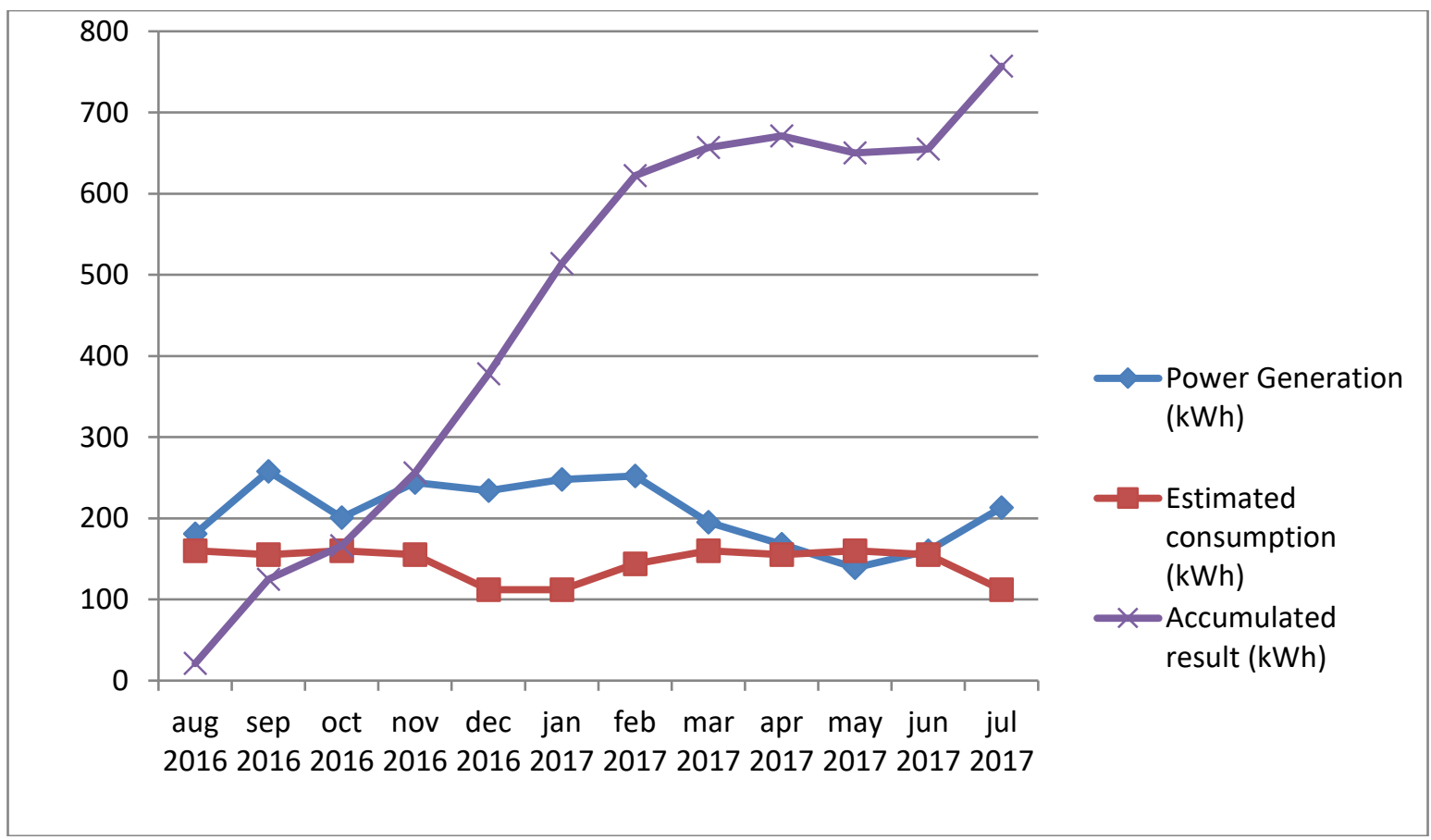

Graph 2 - GO comparison between consumption and energy generation.

Source: Authors

Analyzing Graph 4, it can be observed that the months that contribute the most to the energy surplus coincide with the holiday months. The month of January/2017 presented a record of surplus of energy $(136 \mathrm{kWh})$ for being a non-school month and with high production. In contrast, the month of greatest generation was September/2017 (258 $\mathrm{kWh}$ ), but it was not the one that most collaborated with the network because it was a school month. The month of May / 2017 had the lowest energy production (139 kWh) and was the only one that did not provide power to the grid, requiring $21 \mathrm{kWh}$. 


\section{CONCLUSION}

With the results obtained, it is concluded that the Green Office goes beyond a Zero Energy Building, it is a positive energy construction, that is, it generates more energy than it consumes. The energy production through SFVCR is higher than the Office's consumption, where the estimate indicates that in the analyzed period, it generated a surplus of $757 \mathrm{kWh}$. The result is due to the usage of LED lamps and the contribution of natural lighting, as it reduces the need for artificial lighting.

Another important issue to consider is the fact that it does not require equipment for forced ventilation or heating, since the building has a good thermal load due to the use of insulation materials and cross ventilation techniques.

The consumption scenario adopted in this paper was conservative and to obtain better results in the analysis it is suggested to enlarge the measurement of the real consumption in the building by means of readings and monitoring in the measurer in larger periods of time.

Finally, the study pointed out that the SFVCR of the GO has excellent results in the energy efficiency, it is an excellent alternative to minimize the impacts to the environment and the generation of energy supplies the demand and also exceeds in over $43 \%$ of the need. The GO as a case study and as a teaching tool has, in addition to the energy aspects, other possibilities of research and analysis whose future studies can contemplate.

\section{REFERENCES}

1.Mariano, Juliana D’Angela. Análise do Potencial da Geração de Energia Fotovoltaica para Redução dos Picos de Demanda e Contribuição Energética nas Edificações da UTFPR em Curitiba. 2017. 194 f. Dissertação (Mestrado em Engenharia Civil) - Universidade Tecnológica Federal do Paraná. Curitiba, 2017.

2. Agência Nacional de Energia Elétrica. "Matriz Energética do Brasil". 2017. available in: >https://ben.epe.gov.br/downloads/S\%C3\%ADntese \%20do\%20Relat \%C3\%B3rio\%2 0Final_2017_Web.pdf<. Acess in: 02 ago. 2017.

3. Agência Nacional de Energia Elétrica. "Registros de Micro e Minigeradores distribuídos efetivados na ANEEL". 2017. Available in:

$>$ https://microgeracaofv.wordpress.com/2016/08/06/registros-de-micro-e-minigeracaofotovoltaica-brasil-dados-da-aneel/<. Acess in: 02 ago. 2017.

4. Garcia, A. V.; Oliveira, E. C. A. De; Silva, G. P.; Costa, P. P. Da; Oliveira, L. A. de. Disponibilidade Hídrica e volume de água outorgado na micro-bacia do Ribeirão Abóbora, Município de Rio Verde, Estado de Goiás. Caminhos de Geografia, Uberlândia, v. 8, n.22, 2007. 5. Revista Green Building. Conhecimento em sustentabilidade: Escritório Verde da UTFPR é exemplo de sustentabilidade e busca a certificação de operação e uso do Processo AQUA. Edição 13. available in: $\langle$ http://www.revistagreenbuilding.com.br/projeto.php?id=37>. Acess in: 29 jun. 2017.

6. Oliveira, Allan R.. CAMPOS, Henrique M. v. d. B. Amarante, João G. Study about the energy efficiency of the Green Office of Federal Technological University of Paraná, Curitiba campus.2013. 256 p. Trabalho de conclusão de curso (Engenharia Industrial Elétrica - ênfase em Eletrotécnica), Universidade Tecnológica Federal do Paraná. Curitiba, 2013.

7. Universidade Federal do Rio Grande do Sul. "Programa RADIASOL". Laboratório de Energia Solar. Rio Grande do Sul, 2012.

8. Urbanetz Junior, Jair; Casagrande Junior, Eloy Fassi; Tiepolo, Gerson Máximo. Acompanhamento Do Desempenho Do Sistema Fotovoltaico Conectado À Rede Elétrica Do Escritório Verde Da Universidade Tecnológica Federal do Paraná. Congresso Brasileiro de Planejamento Energético, Florianópolis, ago. 2014. 